\title{
ANALISIS SISTEM KEBERANGKATAN CALON JAMAAH HAJI MENGGUNAKAN METODE WEIGHTED PRODUCT
}

\author{
Jhoanne Fredricka, Muhammad Fikri Ihsan ${ }^{2}$ \\ ${ }^{1}$ Dosen Tetap Program Studi Informatika Fakultas Ilmu Komputer Universitas Dehasen Bengkulu \\ Jl. Meranti Raya No. 32 Kota Bengkulu 38228 Telp. (0736) 22027, 26957 ; e-mail: fredrickajhoanne@gmail.com \\ ${ }^{2}$ Mahasiswa Magister Program Studi Teknik Informatika Universitas Amikom Yogyakarta \\ e-mail:mf.fikri.ihsan@gmail.com
}

\begin{abstract}
The hajj pilgrimage is carried out based on the principles of justice, professionalism and accountability so that the pilgrims can perform their worship in accordance with the provisions of Islamic teachings. In the Ministry of Religion, Bengkulu Province has used an information system in processing data on the departure schedule of prospective pilgrims, but determining the estimated departure schedule is still done manually. This study aims to determine the analysis of the departure schedule for pilgrims using the weighted product method. The weighted product method in managing the departure data is carried out by determining the criteria, namely the age of the congregation, the history of the pilgrimage and the duration of registration based on the calculation of the normalization of the weight and the determination of the vector value, so that the ranking is obtained where the highest value is taken which is the main priority.
\end{abstract}

Key words: Hajj pilgrims, Normalization, Weighted Product.

Intisari — Penyelenggaraan ibadah haji dilaksanakan berdasarkan asas keadilan, profesionalitas, dan akuntabilitas sehingga jamaah haji dapat menunaikan ibadahnya sesuai dengan ketentuan ajaran agama Islam. Di Kementerian Agama Provinsi Bengkulu telah menggunakan sistem informasi dalam pengolahan data jadwal keberangkatan calon jamaah haji, akan tetapi penentuan estimasi jadwal keberangkatannya masih dilakukan secara manual. Penelitian ini bertujuan untuk mengetahui analisa jadwal keberangkatan calon jamaah haji menggunakan metode weighted product. Metode weighted product dalam pengelolahan data keberangkatan dilakukan dengan cara menentukan kriteria yaitu umur jamaah, riwayat haji dan lama pendaftaran berdasarkan perhitungan normalisasi bobot dan penentuan nilai vektor, sehingga diperoleh perengkingan dimana diambil nilai tertinggi yang dijadikan sebagai prioritas utama.

Kata kunci: jamaah Haji, Normalisasi, Weighted Product.

\section{PENDAHULUAN}

Ibadah haji adalah rukun Islam ke lima yang wajib dilaksanakan oleh setiap orang Islam yang memenuhi syarat-syarat, baik secara finansial, fisik, maupun mental. Negara / Pemerintah bertanggung jawab atas penyelenggaraan ibadah haji berdasarkan amanah UUD 1945. Dalam Undang-Undang Nomor 13 Tahun 2008 tentang Penyelenggaraan Ibadah Haji, mengatur mengenai rangkaian kegiatan pengelolaan pelaksanaan ibadah haji yang meliputi pembinaan, pelayanan, dan perlindungan jamaah haji. Penyelenggaraan ibadah haji dilaksanakan berdasarkan asas keadilan, profesionalitas, dan akuntabilitas [7].

Untuk menentukan jadwal keberangkatan calon jamaah haji perlu pertimbangan berdasarkan kriteria-kriteria yang ditetapkan, adapun kriteria tersebut adalah umur jamaah yang lebih tua didahulukan, dengan rentan umur 75 tahun ke atas; riwayat haji, apabila calon jamaah haji sudah pernah haji, maka calon jamaah haji tersebut akan dimundurkan dan calon jamaah haji yang belum pernah sama sekali berangkat haji akan diutamakan; lama mendaftar, lamanya pendaftar calon jamaah haji mempengaruhi keberangkatan haji, apabila sudah mendaftar dengan jarak yang lama maka calon jamaah haji tersebut akan diberangkatkan sesuai dengan kondisi tertentu. Apabila ada suatu keluarga yang mendaftar berangkat haji, prioritas akan tetap menjadi kunci utama dalam keberangkatan, bila dalam suatu keluarga mendaftar serentak maka bukan berarti dalam satu keluarga itu akan berangkat secara bersama langsung karena perhitungan keberangkatan hanya diberlakukan berdasarkan prioritas dari masing-masing pendaftar. Jika kuota dalam pemberangkatan haji ditambah, maka kualifikasi antrian calon jamaah yang akan berangkat 
akan dimajukan mengisi kekosongan dari kuota yang ditambah. Dengan sistem pengolahan data jamaah haji yang ada pada saat ini sangat sulit untuk menentukan jadwal keberangkatan calon jamaah haji karena jadwal keberangkatan hanya diurutkan berdasarkan urutan mendaftar dari jamaah. Oleh karena itu diperlukan suatu metode yang dapat menentukan jadwal keberangkatan calon jamaah haji berdasarkan kriteria-kriteria yang lebih kompleks.

Menurut penelitian sebelumnya yaitu Sistem Informasi Keberangkatan Haji Menggunakan Algoritma Queue With Priority [8], penelitian ini menggunakan metode Queue With Priority dan yang menjadi objeknya adalah calon jamaah haji yang akan berangkat haji di Riau. Hasil dari penelitian ini memprioritaskan jamaah haji yang lebih tepat untuk berangkat haji dengan perhitungan algoritma Queue With Priority.

Sedangkan pada penelitian Penerapan Sistem Pendukung Keputusan Penentuan Prioritas Calon Jamaah Haji Lanjut Usia Menggunakan Metode Simple Additive Weighting [10], dimana pada penelitian ini menggunakan metode Simple Additive Weighting dan yang menjadi objeknya adalah calon jamaah haji di Aceh. Pada penelitian ini ditemukan bahwa pengelompokan kloter haji berdasarkan kriteria lama pendaftaran, kuota keberangkatan, keadaan fisik dan jumlah pendaftar.

Maka pada penelitian ini akan dilakukan urutan keberangkatan dengan metode weighted product. Weighted product merupakan metode penyelesaian dengan menggunakan perkalian untuk menghubungkan rating atribut, dimana rating harus dipangkatkan terlebih dahulu dengan bobot atribut yang bersangkutan. Metode ini digunakan untuk menentukan bobot teratas dari kriteria-kriteria yang ditetapkan. Keunggulan dari metode Weighted product ini yaitu dapat digunakan pada proses nilai yang memiliki nilai rentang sehingga dapat diimplementasikan dalam penentuan jadwal keberangkatan calon jamaah haji.

\section{TINJAUAN PUSTAKA}

\section{A. Haji}

Haji berasal dari bahasa Arab yaitu al-hajju yang berarti al-qashdu yaitu menyengaja atau menuju, bermaksud, berniat pergi atau berniat untuk mendatangi seseorang yang dipandang mulia, yang dimaksud dengan berniat dalam pengertian ini adalah berniat untuk melakukan sesuatu yang baik ditempat tertentu, karena tempat itu dipandang mulia atau terhormat. Dalam istilah syara', al-hajju berarti sengaja mengunjungi Ka'bah untuk melakukan ibadah tertentu, pada waktu tertentu dengan melakukan suatu pekerjaan tertentu.

Haji menurut bahasa ialah menuju kesuatu tempat berulang kali atau menuju kepada sesuatu yang dibebaskan [9]. Haji asal maknanya adalah menyengaja sesuatu. Haji yang dimaksud dinisi ialah menyengaja mengunjungi Ka'bah (Rumah Suci) untuk melakukan beberapa amal ibadat, dengan syarat-syarat yang tertentu [6].

Kewajiban haji adalah sekali dalam seumur hidup, sedang selebihnya adalah sunnah. Syarat-syarat wajib haji adalah kondisi yang apabila terdapat dengan sempurna seluruhnya bagi seorang, berarti ia wajib pergi menunaikan haji. Tetapi jika tidak terdapat seluruhnya atau sebagiannya, walaupun satu diantaranya, maka ia tidak wajib menunaikan haji [3]

\section{B. Basis Data (Database)}

Basis data (database) adalah kumpulan data yang disimpan secara sistematis di dalam komputer yang dapat diolah atau dimanipulasi menggunakan perangkat lunak untuk menghasilkan informasi [2]. Pendefinisian basis data meliputi spesifikasi berupa 
tipe data, struktur data dan juga batasan-batasan pada data yang akan disimpan. Basis data merupakan aspek yang sangat penting dalam sistem informasi karena berfungsi sebagai gudang penyimpanan data yang akan diolah lebih lanjut. Basis data menjadi penting karena dapat mengorganisasi data, menghidari duplikasi data, menghindari hubungan antar data yang tidak jelas dan juga update yang rumit

\section{Sistem Pendukung Keputusan}

Sistem Pendukung Keputusan didefinisikan sebagai sebuah sistem yang mendukung kerja seorang manajer maupun sekelompok manajer dalam memecahkan masalah semi terstruktur dengan cara memberikan informasi ataupun usulan menuju pada keputusan tertentu [1].

Decision Support System (DSS) adalah sistem informasi interaktif yang menyediakan informasi, pemodelan, dan pemanipulasian data [4]. Sistem itu digunakan untuk membantu pengambilan keputusan dalam situasi yang semi terstruktur dan situasi yang tidak terstruktur.

\section{Weighted product (WP)}

Weigthted Product adalah metode penyelesaian dengan menggunakan perkalian untuk menghubungkan rating atribut, dimana rating harus dipangkatkan terlebih dahulu dengan bobot atribut yang bersangkutan. Proses ini sama halnya dengan proses normalisasi [5].

Langkah-langkah penyelesaian WP sebagai berikut:

1. Menentukan kriteria-kriteria

Yaitu kriteria yang akan dijadikan acuan dalam pengambilan keputusan, yaitu $\mathrm{Cn}$ dan sifat dari masing-masing kriteria.

2. Menentukan rating kecocokan
Yaitu rating kecocokan setiap alternatif pada setiap kriteria, dan buat matriks keputusan.

3. Melakukan normalisasi bobot

a. Bobot Ternormalisasi $=$ Bobot setiap kriteria/penjumlahan semua bobot kriteria. Dengan cara menjumlahkan setiap masingmasing poin kriteria tertinggi yang telah ditetapkan.

$$
\sum W_{\text {total }}
$$

Simbol $W_{\text {total }}$ adalah jumlah dari poin kriteria yang telah ditetapkan

b. Nilai dari total bobot harus memenuhi persamaan:

$$
W_{n}=\frac{w_{\max }}{\Sigma w_{\text {total }}}
$$

Keterangan :

$W_{n} \quad=$ menyatakan poin kriteria

$W_{\max } \quad=$ nilai poin tertinggi dari pilihan

poin kriteria

4. Menentukan nilai vektor $\mathrm{S}$

Dengan cara menjumlahkan seluruh kriteria dengan bobot sebagai pangkat positif untuk kriteria benefit.

Rumus untuk menghitung nilai preferensi untuk alternatif, diberikan sebagai berikut:

$$
S=C_{1}^{W n_{1}}+C_{2}^{W n_{2}}+C_{3}^{W n_{3}}+C_{4}^{W n_{4}}+\ldots . C_{n}^{W n}
$$

Keterangan:

S : menyatakan nilai bobot kriteria yang

dianalogikan sebagai vektor $\mathrm{S}$

$\mathrm{C}$ : menyatakan nilai kriteria

$\mathrm{w}$ : menyatakan poin kriteria

5. Menentukan Perankingan dari Nilai Vektor yang didapat

Ranking 1 -> v2 $=\ldots$.

Ranking $2->\mathrm{v} 1=\ldots$

Ranking 3 -> v3 $=\ldots$ 
Sekaligus membuat kesimpulan sebagai tahap akhir.

\section{III.METODOLOGI PENELITIAN}

\section{A. Jenis, Sifat dan Pendekatan Penelitian}

Jenis penelitian ini adalah studi kasus, dimana penelitian ini tidak melakukan tindakan tetapi mengamati fenomena yang terjadi terkait dengan objek yang sedang di amati. Karena data yang diambil yaitu berupa data - data calon jamaah yang akan berangkat haji, sehingga akan dilakukan analisa tentang sistem dari keberangkatan calon jamaah haji tersebut.

Penelitian ini bersifat deskritif, karena penelitian ini tidak bertujuan untuk menguji hipotesa penelitian tetapi hanya memberikan gambaran analisa bagaimana sistem penentuan keberangkatan calon jamaah haji. Penelitian ini juga berupaya untuk melakukan pencarian terhadap fakta dengan memberikan interprestasi yang tepat terhadap data dengan tujuan untuk membuat deskripsi atau gambaran secara sistematis dan fakta - fakta mengenai permasalahan yang peneliti selidiki.

Dalam penelitian ini, peneliti menggunakan pendekatan ilmiah yang bersifat kualitatif, dimana dapat diartikan bahwa penelitian ini bersifat bias/prasangka, penilaian dan pendapat peneliti tertuang secara eksplisit di dalam laporan riset, meskipun hal tersebut di anggap sesuatu yang sangat berguna dan positif atau tidak disangsikan. Namun tidak menutup kemungkinan untuk menggunakan data - data kuantitatif yang terkait dengan subjek ataupun masalah penelitian dalam memperkuat data - data yang terkumpul selama dilakukan penelitian.

\section{B.Metode Pengumpulan Data}

Metode pengumpulan data adalah salah satu teknik mendapatkan data - data akurat yang diperlukan untuk saling menunjang dan melengkapi dalam penulisan ini, yakni ada beberapa metode yang dapat digunakan yaitu:

a. Study pustaka, yaitu cara mengumpulkan data data dan mempelajari sumber pustakaan yang dapat mendukung penelitian, bentuk study pustaka dapat berupa buku, artikel, jurnal, file atau dokumen terkait.

b. Observasi, yaitu merupakan cara mengumpulkan data secara langsung dilapangan sehingga memperoleh data yang lebih akurat sebagai penunjang penelitian.

c. Wawancara, yaitu merupakan tindakan Tanya jawab kepada pihak terkait guna untuk mendapatkan informasi yang dibutuhkan.

\section{IV.HASIL DAN PEMBAHASAN}

\section{A. Pengolahan Data Awal}

Data yang digunakan dalam penelitian ini adalah data yang di dapatkan dari hasil wawancara dan observasi langsung pada objek penelitian dimana dalam hal ini peneliti melakuakn wawancara pada salah satu pegawai pada kantor kementrian agama Provinsi Bengkulu. Data yang di peroleh di gunakan untuk melakukan perhitungan menggunakan metode Weigthted Product(WP) dimana akan di peroleh jumlah perhitungan atribut yang nanti akan digunakan untuk melihat persentase perhitungan dalam menentukan jadwal keberangkat para calon jamaah haji provinsi Bengkulu.

\section{B. Perhitungan Menggunakan Metode Weighted}

\section{Product}

Untuk menentukan persentase tertinggi yang akan menjadi prioritas utama dalam penentuan keberangkatan jamaah haji akan dilakukan perhitungan dengan menggunakan metode weighted product. Perhitungan dilakukan setelah menetukan 
beberapa kriteria dengan mengambil beberapa buah sample data.

Tabel 1. Kriteria Umur Jamaah

\begin{tabular}{|c|c|}
\hline Umur & Point \\
\hline$\geq 75$ & 8 \\
\hline $71-74$ & 7 \\
\hline $66-70$ & 6 \\
\hline $61-65$ & 5 \\
\hline $51-60$ & 4 \\
\hline $40-50$ & 3 \\
\hline $29-39$ & 2 \\
\hline $18-28$ & 1 \\
\hline
\end{tabular}

Tabel 2. Kriteria Status Jamaah

\begin{tabular}{|c|c|}
\hline Status Kepergian & Point \\
\hline Belum Haji & 3 \\
\hline Pernah Haji & 1 \\
\hline
\end{tabular}

Tabel 5. 3 Status Pendaftaran Jamaah

\begin{tabular}{|c|c|}
\hline $\begin{array}{c}\text { Status } \\
\text { Pendaftaran }\end{array}$ & Point \\
\hline$\geq 20$ & 5 \\
\hline $16-19$ & 4 \\
\hline $11-15$ & 3 \\
\hline $6-10$ & 1 \\
\hline $1-5$ & \\
\hline
\end{tabular}

Selanjutnya kita akan melakuan normalisasi bobot, untuk menentukan nilai vector $\mathrm{S}$ serta menentukan perangkingan dari nilai vector yang telah di dapat.
Sample 1:

$$
\begin{aligned}
& \text { Umur } \quad=55 \text { Tahun } \quad->4 \\
& \text { Riwayat = Belum Haji } \quad->3 \\
& \text { Lama Mendaftar = } 10 \text { Tahun } \quad->2 \\
& \text { Wtotal }=8+3+5=16 \\
& \text { - } W_{1}=\frac{W_{U m u r}}{W_{\text {Total }}} \\
& W_{1}=\frac{4}{8+3+5} \\
& W_{1}=\frac{4}{16}=0,25 \\
& \text { - } W_{2}=\frac{W_{\text {Riwayat }}}{W_{\text {Total }}} \\
& W_{2}=\frac{3}{8+3+5} \\
& W_{2}=\frac{3}{16}=0,18
\end{aligned}
$$

Sample 2:

$$
\begin{array}{lll}
\text { Umur } & =76 \text { Tahun } & ->8 \\
\text { Riwayat } & =\text { Belum Haji } & ->3 \\
\text { Lama Mendaftar } & =8 \text { Tahun } & ->2 \\
\text { Wtotal } & =8+3+5=16
\end{array}
$$$$
\text { - } W_{1}=\frac{W_{\text {Umur }}}{W_{\text {Total }}}
$$$$
W_{1}=\frac{8}{8+3+5}
$$$$
W_{1}=\frac{8}{16}=0,5
$$$$
\text { - } W_{2}=\frac{W_{\text {Riwayat }}}{W_{\text {Total }}}
$$$$
W_{2}=\frac{3}{8+3+5}
$$$$
W_{2}=\frac{3}{16}=0,18
$$

Sample 3:

$$
\begin{array}{lll}
\text { Umur } & =20 \text { Tahun } & ->1 \\
\text { Riwayat } & =\text { belum Haji } & ->3 \\
\text { Lama Mendaftar } & =3 \text { Tahun } & ->1 \\
\text { Wtotal } & =8+3+5=16
\end{array}
$$

- $\quad W_{1}=\frac{W_{U m u r}}{W_{\text {Total }}}$ 


$$
\begin{aligned}
W_{1} & =\frac{1}{8+3+5} \\
W_{1} & =\frac{1}{16}=0,06 \\
W_{2} & =\frac{W_{\text {Riwayat }}}{W_{\text {Total }}} \\
W_{2} & =\frac{3}{8+3+5}, \\
W_{2} & =\frac{3}{16}=0,18 \\
S=C_{1}^{W n_{1}} & +C_{2}^{W n_{2}}+C_{3}^{W n_{3}}+C_{4}^{W n_{4}}+\ldots . C_{n}^{W n}
\end{aligned}
$$

Sample 1:

$$
\begin{aligned}
S & =4^{0,25}+3^{0,18}+2^{0,12} \\
& =1,41+1,21+1,08 \\
& =3,7
\end{aligned}
$$

Sample 2:

$$
\begin{aligned}
S & =8^{0,5}+3^{0,18}+2^{0,12} \\
& =2,82+1,21+1,08 \\
& =5,11
\end{aligned}
$$

Sample 3:

$$
\begin{aligned}
S & =1^{0,06}+3^{0,18}+1^{0,06} \\
& =1+1,21+1 \\
& =3,21
\end{aligned}
$$

Berdasarkan perhitungan dari ketiga buah sample data maka didapatkan hasil perengkingan yaitu ranking 1 adalah Sample $2=5,11$, ranking 2 adalah sample $1=3,7$ dan ranking 3 adalah sample $3=3,21$, dengan demikian dapat di analisa bahwa sample 2 yang akan menjadi prioritas utama.

\section{KESIMPULAN}

Berdasarkan hasil penelitian dan pembahasan, maka dapat di simpulkan bahwa sistem penentuan jadwal keberangkatan calon jamaah haji dapat di analisa dengan melakukan perhitungan menggunakana metode Weighted Product (WP). Data dapat dikelola dengan cara menentukan kriteria-kriteria berdasarkan variabel-variabel yang telah ditentukan, dengan melakukan perhitungan normalisasi bobot berdasarkan sample yang digunakan, menentukan nilai vektor, dan diperoleh hasil perangkingan dari nilai vektor yang telah dihitung, selanjutnya dilakukan pengambilan nilai tertinggi dari perhitungan untuk dijadikan prioritas utama.

\section{DAfTAR PUSTAKa}

[1] Hermawan, Julius. (2005). Membangun Decision Support System. Yogyaarta: Andi

[2] Hindro. (2017, March 27). Pengertian MySQL Menurut Para Ahli. Retrieved from https://www.termasmedia.com/lainnya/software /69-pengertian-database.html

[3] Ja'far, Muhammadiyah. (1997). Tuntunan Ibadat Zakat Puasa dan Haji. Jakarta: Kalam Mulia.

[4] Kusrini. (2007). Konsep dan Aplikasi Sistem Pendukung Keputusan. Yogyakarta: Andi.

[5] Kusumadewi, Sri. (2006). Fuzzy Multi AttributeDecision Making. Yogyakarta: Graha Ilmu.

[6] Rasjid, Sulaiman. (1989). Fiqh Islam. Bandung: Sinar Baru.

[7] Republik Indonesia. (2008). Undang-Undang Republik Indonesia Nomor 13 Tahun 2008 Tentang Penyelenggraan Ibadah Haji. Retrieved from 
https://kemenag.go.id/file/dokumen/UU1308.pd

$\mathrm{f}$

[8] Salman, D. P. (2015). Sistem Informasi Keberangkatan Haji Menggunakan Alogaritma Queue With Priority. Laporan Bacaan Proyek Akhir. Politeknik Caltex Riau. Riau.

[9] Shiddieqy, Hasbi. (1994). Pedoman Haji. Jakarta: PT Bulan Bintang.

[10] Sriwinar. (2014). Penerapan Sistem Pendukung Keputusan Penentuan Prioritas Calon Jamaah Haji Lanjut Usia Menggunakan Metode Simple Additive Weighting. Jurnal Ilmiah Sains, Teknologi, Sosial dan Budaya, 1(2). 